\title{
Oral rinses in growth inhibition and treatment of Helicobacter pylori infection
}

\author{
Dharmendra Kashyap ${ }^{1 \dagger}$, Budhadev Baral ${ }^{1 \dagger}$, Tarun Prakash Verma ${ }^{1}$, Charu Sonkar ${ }^{1}$, Debi Chatterji ${ }^{2}$, \\ Ajay Kumar Jain ${ }^{2}$ and Hem C. Jha ${ }^{* *}$
}

\begin{abstract}
Background: Helicobacter pylori (H. pylori) is well-known for its role in chronic gastritis and gastric cancer. Eradication of these carcinogenic bacteria from the gut is one of the challenges for clinicians. The complexity of treatment mainly owes to antibiotic resistance and relapse due to an additional reservoir in the oral cavity. Our study emphases the isolation of $\mathrm{H}$. pylori from distinct habitats of the gut microenvironment (gastric biopsy and gastric juice) and its subsequent characterization. We have also evaluated the effect of various oral rinses on isolated H. pylori from different anatomical locations of included subjects.
\end{abstract}

Results: The possible strains isolated from two different habitats of the same subject shows a striking difference in their growth pattern. Promisingly, some of the included oral rinses are efficient in growth inhibition as per recommended 30 s treatment. The subsequent evaluation shows that oral rinse B (among A-E) is most effective and down-regulates the expression of one of the potent $H$. pylori gene, CagA, in the infected gastric adenocarcinoma (AGS) cells.

Conclusion: Our study, for the first time, revealed that H. pylori, isolated from the different habitat of the same subject, show a different growth pattern. The expression of $\mathrm{H}$. pylori pathogenic gene (CagA) was down-regulated by the use of oral rinses. Hence, oral rinses will reduce the H. pylori in the oral cavity and help to control its migration from oral to the gastric compartment and may be used as an adjuvant treatment option for its reinfection.

Keywords: Gastric cancer, Oral rinses, CagA, Apoptotic pathway, Growth curve, H. pylori, Gastritis

\section{Background}

Helicobacter pylori play a vital role in the development of various gastro-duodenal diseases [1]. Usually, healthy microflora produces a bacteriocin-like inhibitory protein that inhibits $H$. pylori growth [2]. The number of $H$. pylori may increase due to loss in healthy microflora. Subsequently, it leads to the production of gastric acid, followed by ulceration [3]. Some strains of H. pylori are virulent, and host factors may also be responsible for disease progression [4]. Additionally, other bacteria that are acid-tolerant might also reside at the infection site within ulcers and thus enhance the problem caused by H. pylori [5].

\footnotetext{
* Correspondence: hemcjha@iiti.ac.in

${ }^{\dagger}$ Dharmendra Kashyap and Budhadev Baral contributed equally to this work. ${ }^{1}$ Discipline of Biosciences and Biomedical Engineering, Indian Institute of Technology Indore, 453552 Indore, Madhya Pradesh, India

Full list of author information is available at the end of the article
}

Worldwide, H. pylori have been classified according to population genetics tool (STRUCTURE) developed by Pritchard et al. [6, 7]. Broadly, they represent geographical areas and named as: hpEurope, hpSahul, hpEastAsia, hpAsia2, hpNEAfrica, hpAfrica1 and hpAfrica2 [8]. Also, there is a large variability in the occurrence of gastric cancer (GC) worldwide [9]. Asian countries such as South Korea, China, and Japan have a high incidence of $\mathrm{GC}$ [10]. India is a low-risk country for GC; however, it may be attributed to underreporting [11]. There lies a lacuna in the epidemiological studies and reporting from small towns and villages, which represents a large part of the Indian population [12].

$H$. pylori seroprevalence in the adult population of developing countries varies from 55 to $92 \%$. In contrary to this, the seroprevalence of $H$. pylori in Chinese and Japanese adults is 44 and 55\%, respectively [13]. The primary manifestation of $H$. pylori in India is the

(C) The Author(s). 2020 Open Access This article is distributed under the terms of the Creative Commons Attribution 4.0 International License (http://creativecommons.org/licenses/by/4.0/), which permits unrestricted use, distribution, and 
duodenal ulcer, which is a major concern [14]. A study suggested that $56 \%$ of $H$. pylori infection contributes to the leading cause of GC [15]. Therefore, a comprehensive study of $H$. pylori strains and its pathogenic properties is crucial in the Indian scenario.

H. pylori may be transmitted through an oral-oral or oro-fecal route, and thus oral cavity may act as its possible reservoir [16]. Its presence in the oral cavity is seldom eliminated by $H$. pylori eradication therapy [17]. Moreover, the oral site may act as a source for reinfection, which is found to be as high as $60 \%$ in Indian subjects $[18,19]$. Hence, its eradication from oral microenvironment is essential [20, 21]. Several antimicrobial (e.g., bisbiguanides, metal ions, phenols and quaternary ammonium compounds) and antiplaque agents (e.g., surfactants and essential oils) in the form of toothpaste and mouth rinses have been formulated [22]. Antiplaque agents destroy bacterial biofilm, which prevents adherence and growth of bacteria, while antimicrobial agents inhibit the growth or kill the target bacteria [23].

Importantly, many virulent strains of $H$. pylori harbor numerous adhesins (BabA/B, SabA, AlpA/B, OipA and HopZ) and the cag (cytotoxin-associated genes) pathogenicity island encoding a type IV secretion system (T4SS) [24]. A tight bacterial contact with the host cell may get established by the adhesins [25]. Moreover, bacterial effector proteins like CagA is delivered into host cells through this secretion system [26]. A study also mentioned that $H$. pylori colonization might also depend on the alteration of mucosal epithelial apoptosis by chronic inflammation [27]. Surprisingly, the relation between various $H$. pylori serotypes, their growth alone, or with gastric epithelial microenvironment in order to the possible occurrence in $\mathrm{GC}$ has not been evaluated to date. Investigation of $H$. pylori strains for their growth, and subsequent host cell transformation ability may open better understanding in this domain. Hence, the present study was designed to evaluate the growth pattern of various clinical isolates of $H$. pylori and their response to treatment with commercially available oral rinses/solution. The study also includes the evaluation of tumor suppressor and proto-oncogene status in gastric epithelial cells as a response to treated and untreated isolates of $H$. pylori.

\section{Results}

Gastric biopsy and juice collection from gastritis patients for isolation of $\boldsymbol{H}$. pylori

To date, there are no H. pylori isolates reported from central India to the best of our knowledge. Moreover, isolates from northern and southern India have been listed in previous reports [28]. H. pylori were successfully isolated from five out of 14 biopsy samples and four out of 11 juice samples (Table 1). After observation in
Table 1 Gastric biopsy and juice collection from gastritis patients

\begin{tabular}{|c|c|c|c|c|c|c|}
\hline \multirow{3}{*}{$\begin{array}{l}\text { Sr. } \\
\text { No. } \\
1\end{array}$} & \multicolumn{2}{|c|}{ Sample } & \multirow{3}{*}{$\begin{array}{l}\text { Sex } \\
F\end{array}$} & \multirow{3}{*}{$\begin{array}{l}\begin{array}{l}\text { RUT } \\
\text { status }\end{array} \\
+\end{array}$} & \multicolumn{2}{|c|}{ Grown sample } \\
\hline & \multirow{2}{*}{$\begin{array}{l}\mathrm{HB} \\
\checkmark\end{array}$} & \multirow{2}{*}{$\frac{\overline{H J}}{\sqrt{\mathrm{H}}}$} & & & & \\
\hline & & & & & HB1 & $\mathrm{HJ1}$ \\
\hline 2 & $\checkmark$ & $\checkmark$ & M & + & - & - \\
\hline 3 & $\checkmark$ & $\checkmark$ & M & + & - & - \\
\hline 4 & $\checkmark$ & $x$ & M & + & HB4 & - \\
\hline 5 & $\checkmark$ & $x$ & M & + & HB5 & - \\
\hline 6 & $\checkmark$ & $x$ & M & + & - & - \\
\hline 7 & $\checkmark$ & $\checkmark$ & M & + & - & - \\
\hline 8 & $\checkmark$ & $\checkmark$ & F & + & - & - \\
\hline 9 & $\checkmark$ & $\checkmark$ & F & + & - & HJ9 \\
\hline 10 & $\checkmark$ & $\checkmark$ & M & + & HB10 & $\mathrm{HJ} 10$ \\
\hline 11 & $\checkmark$ & $\checkmark$ & M & + & - & - \\
\hline 12 & $\checkmark$ & $\checkmark$ & M & + & - & - \\
\hline 13 & $\checkmark$ & $\checkmark$ & $\mathrm{F}$ & + & - & - \\
\hline 14 & $\checkmark$ & $\checkmark$ & $\mathrm{F}$ & + & HB14 & HJ14 \\
\hline
\end{tabular}

RUT Rapid Urease Test, $H B$ Gastric Biopsy, HJ Gastric Juice, $M$ Male, $F$ Female

antibiotic selective media, Gram staining was performed on all isolates (Fig. 1). Further, three clinical isolates from biopsies and one from juice were subjected for the amplification of $H$. pylori (16 s rRNA) through qRT-PCR (data not shown). Additionally, validation of the clinical isolates was confirmed through nucleotide sequencing (data not shown). Furthermore, the growth of bacteria may be attributed to its pathogenic ability; hence we have studied the growth pattern of the isolated H. pylori and compared it with the reference strain (I10).

\section{The growth pattern of different clinical isolates of $H$. pylori}

The growth curve of confirmed strains of $H$. pylori was determined by recording OD at $600 \mathrm{~nm}$ at various time points $(0,2,6,12,18$, and $24 \mathrm{~h})$ and a curve was plotted (Fig. 2 a). Our results revealed that the growth of two clinical strains, namely $\mathrm{HB} 1$ and HB5 was significantly faster $(p<0.05)$ compared to the other seven clinical and one reference strain (I10). Interestingly, HB1 and HB5 have similar while not identical growth patterns at all examined time points (Fig. 2a). It is also fascinating that the growth pattern of $\mathrm{HB} 1$ and HJ1 was quite different, even though they were isolated from the same patient (Fig. 2a) Other clinical strains (HB4, HJ9, HJ10, HB10, HJ14, and HB14) shows a similar growth pattern as I10 until 24 $\mathrm{h}$.

To better understand the growth pattern of isolated H. pylori, graphs were plotted in the form of a bar chart at all recorded time points $(0,2,6,12,18$, and $24 \mathrm{~h})$ and were compared with the reference strain (I10) (Fig. 2b). Three to five folds faster growth was observed in 

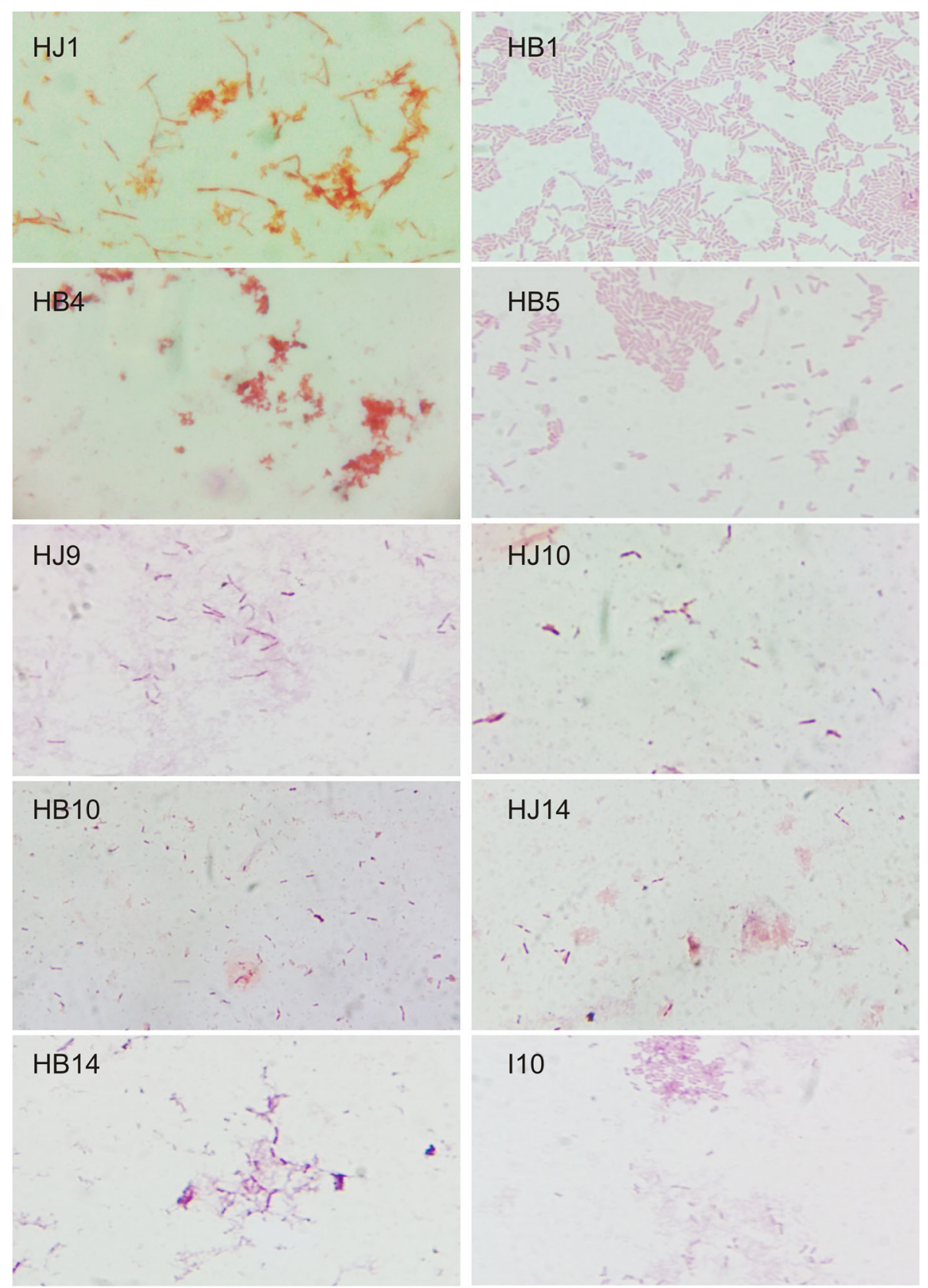

110

Fig. 1 Identification of bacteria through Gram staining. Gram staining of different clinical isolates of H. pylori, namely, I10, HJ9, HB10, HJ10, HB14, $\mathrm{HJ} 14, \mathrm{HB1}, \mathrm{HJ} 1, \mathrm{HB} 4$, and HB5 were showing typical gram-negative bacteria

$\mathrm{HB} 1$ and HB5 compared to $\mathrm{I} 10$ at $2 \mathrm{~h}$, and further, it increased up to $24 \mathrm{~h}$ (Fig. 2b). Moreover, isolates such as HJ1, HB10, and HB14 were showing moderately higher growth (3 to 5 folds) compared to reference strain I10 from $6 \mathrm{~h}$ onwards (Fig. 2b). Importantly, the growth of HB1 and HB5 was steadily increasing up to $18 \mathrm{~h}$. Hence, our study reflected two fast-growing strains (HB1 and HB5) compared to other clinical isolates HJ1, HB4, HJ9, HJ10, HB10, HB14, HJ14, and reference strain I10 (Fig. 2b).

\section{Confirmation of active component of oral rinses through LC-MS}

The active components in the oral rinses of $\mathrm{A}, \mathrm{B}, \mathrm{C}, \mathrm{D}$, and $\mathrm{E}$ was reconfirmed through LCMS at the Sophisticated Instrument Centre facility at IIT Indore (Supp. Fig. 2). The results validate the presence of labeled active components in them. We have got exact mass spectra at 304.5, 253, 205.1, 212.1, and 102.12 for CPC, chlorhexidine, clove oil, thymol, and povidone/iodine respectively (Supp. Fig. 2). Further, to evaluate the efficacy of 

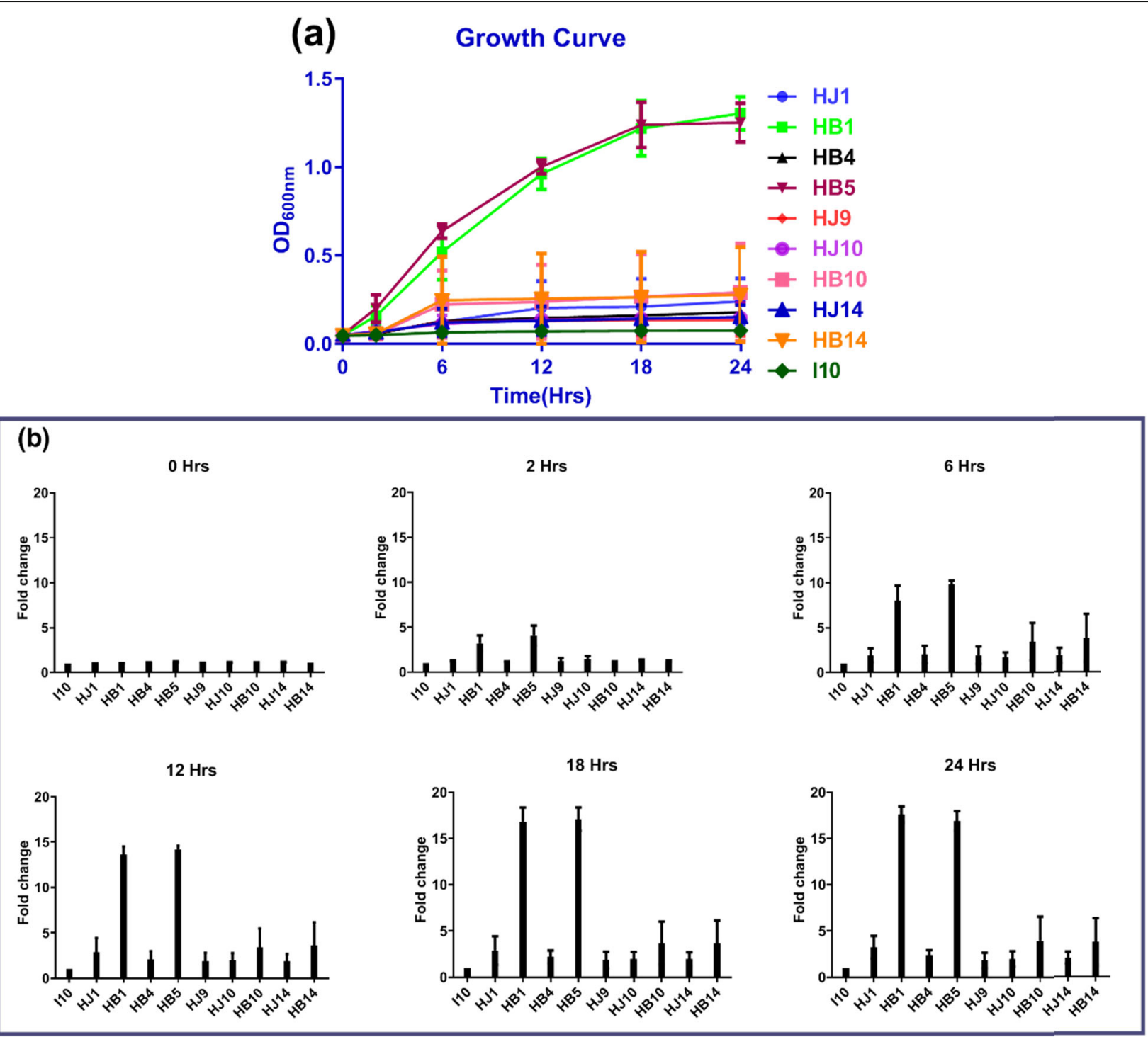

(c)

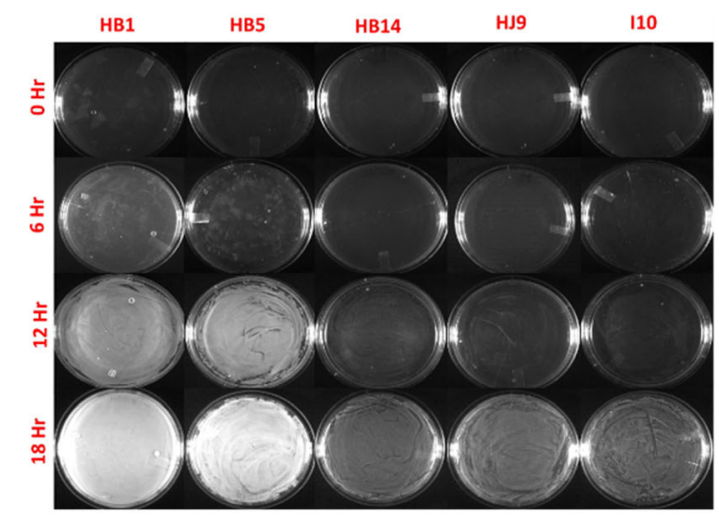

(d)

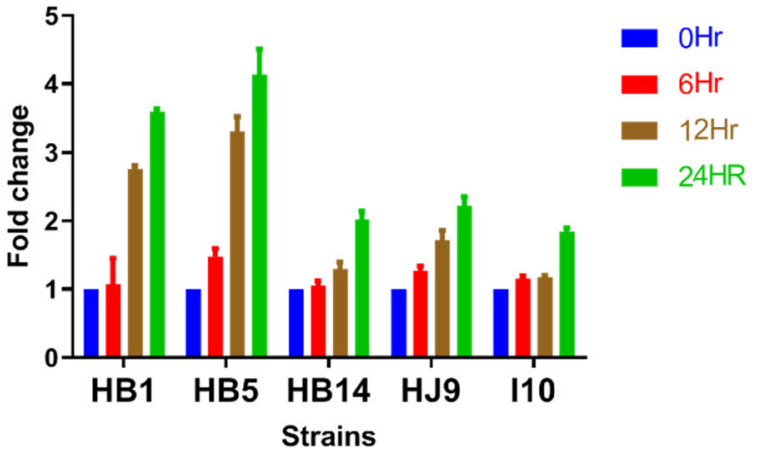

Fig. 2 (See legend on next page.) 
(See figure on previous page.)

Fig. 2 Growth pattern of isolated H. pylori strains. a The growth pattern of clinical isolates (HJ1, HB1, HB4, HB5, HJ9, HJ10, HB10, HJ14, HB14) and reference strain (110) under specific microaerophilic condition assessed at 0,6,12, 18 and $24 \mathrm{~h}$. The data are the mean \pm SD $(n=4)$ of two independent experiments with technical replicate. b: Graphs are plotted for relative growth in comparison to I10 at 0, 2, 6, 12, 18, and 24 h. c Plate densitometry image of selected H. pylori isolates HB1 (lane first); HB5 (lane second); HB14 (lane third); HJ9 (lane fourth); and I10 (lane fifth) are showing growth till $24 \mathrm{~h}$. The experiment is performed in duplicates, and the representative images are shown. $\mathbf{d}$ Fold change was calculated in comparison to $0 \mathrm{Hr}$

selected oral rinses $H$. pylori growth analysis after treatment was performed.

\section{The growth pattern of selected clinical isolates of $H$. pylori after treatment with oral rinses}

All chosen oral solutions recommend $30 \mathrm{~s}$ oral rinsing for effective plaque control. Further, our two fastgrowing (HB1 and HB5), two slow-growing (HJ9 and HB14), and a reference strain (I10) were selected for this experiment (Fig. 3a, b, c, d). Interestingly, we observed that oral rinses $\mathrm{A}$ and $\mathrm{C}$ were not able to stop the growth of fast-growing strain after $30 \mathrm{~s}$ treatment (Fig. 3a). Although, growth of fast-growing strain was again increased after $2 \mathrm{~h}$ post-treatment with solution $\mathrm{A}$ and $\mathrm{C}$ while solution $\mathrm{B}, \mathrm{D}$, and $\mathrm{E}$ were able to inhibit the growth until $24 \mathrm{~h}$ post-treatment. We have found that solution A was least efficient in the control of HB1 growth followed by C. The substantial growth of HB1 was observed from $6 \mathrm{~h}$ onwards when treated with solution $\mathrm{A}$ and $12 \mathrm{~h}$ post-treatment when treated with oral rinse $\mathrm{C}$ (Fig. 3c). Moreover, the growth of another fast-growing strain, HB5, treated with oral rinses $\mathrm{A}$ and $\mathrm{C}$, was suppressed until only $2 \mathrm{~h}$ (Fig. 3c). There was considerable growth of HB5; $6 \mathrm{~h}$ onwards with $\mathrm{A}$, and $\mathrm{C}$ treatment. Importantly, oral rinses $\mathrm{B}, \mathrm{D}$, and $\mathrm{E}$ were able to suppress the growth of HB1 and HB5 until $24 \mathrm{~h}$ in this study (Fig. 3a, c). Additionally, slow-growing strain such as HJ9 and HB14 were not able to grow until $12 \mathrm{~h}$ with all used oral solutions (Fig. 3b). However, these strains start growing from $12 \mathrm{~h}$ onwards when treated with solution C (Fig. 3b). Notably, our reference strain, I10, has not shown any growth after treatment with all oral rinses until $24 \mathrm{~h}$ (Fig. 3b, d). In all these experiments, we have used untreated strains as positive controls and culture media as a negative control. A combination of effective oral rinses was used to evaluate their efficacy on treatment for a shorter duration.

\section{Selective oral rinse are restricting $H$. pylori growth even at shorter exposure}

Oral rinse $\mathrm{B}, \mathrm{D}$, and $\mathrm{E}$ were found to be effective in controlling the growth of slow as well as fast-growing strains at $30 \mathrm{~s}$ treatment. Hence, we investigated the effect of these selected solutions, alone (B, D, and $\mathrm{E})$ and in combination, (BD, BE, DE, and $\mathrm{BDE})$ for a shorter duration of treatment $(5 \mathrm{~s})$ compared to recommended $30 \mathrm{~s}$ (Fig. 4a, b). Even the $5 \mathrm{~s}$ treatment to fast-growing $H$. pylori isolates with all efficacious oral rinses alone and in combination were able to restrict the growth until $2 \mathrm{~h}$ (Fig. 4a, c). Surprisingly, data recorded $6 \mathrm{~h}$ posttreatment were demonstrating the growth of $\mathrm{HB} 1$ and HB5 with D, E, and their combinations. Importantly, all groups in which solution $B$ is included shows to be restricting the growth of HB1 and HB5 (Fig. 4a, c). Interestingly, the growth of slow-growing strains HJ9, HB14, and reference strain I10, completely abolished with all the above solution combinations till $24 \mathrm{~h}$ (Fig. 4b). Moreover, when we treated these oral rinses for $10 \mathrm{~s}$ alone and in combination, a similar pattern was established as with $30 \mathrm{~s}$ (Suppl. Fig. 1).

The growth pattern of $H$. pylori after oral rinses treatment on $\mathrm{BHI}$ agar plate

In addition to solution treatment in liquid culture, we further evaluated the growth pattern of $H$. pylori isolates on a BHI agar plate after $30 \mathrm{~s}$ treatment with the selected oral rinse solution. Representative pictures of solution treated H. pylori strains are shown in Fig. 5a, b, $c$, d, and e. The images were quantified using Image $J$ software (NIH), and graphs were plotted (Fig. 5f, g, h, i, j). As expected, solution treatment of $\mathrm{C}$ was ineffective, and $H$. pylori growth was observed in the case of fastgrowing HB1 and HB5 after $12 \mathrm{~h}$ (Fig. 5a, b, f, g). Moreover, we also witnessed growth after $24 \mathrm{~h}$ for slowgrowing strains (I10, HJ9, and HB14). Surprisingly, no growth was observed in the case of oral rinse A treatment in all the strains, contrary to the growth in liquid culture (Fig. 5). Again, as expected, no growth was detected after treatment with oral rinses B, D, and $\mathrm{E}$ at all the recorded time points. The solutions inhibit the $H$. pylori growth differentially; hence further, investigation of the known gastric cancer markers and $H$. pylori genes to assess the effect of oral rinses on its pathogenicity.

\section{Gene profiling of specific gastric cancer marker and $\mathrm{H}$. pylori after oral rinse treatment}

Expression of $H$. pylori genes, namely $16 \mathrm{~s}$ rRNA, Cag A, and $\mathrm{Bab} \mathrm{A}$, were investigated in this experiment. Additionally, reported GC markers such as CCND1, CDX2, 


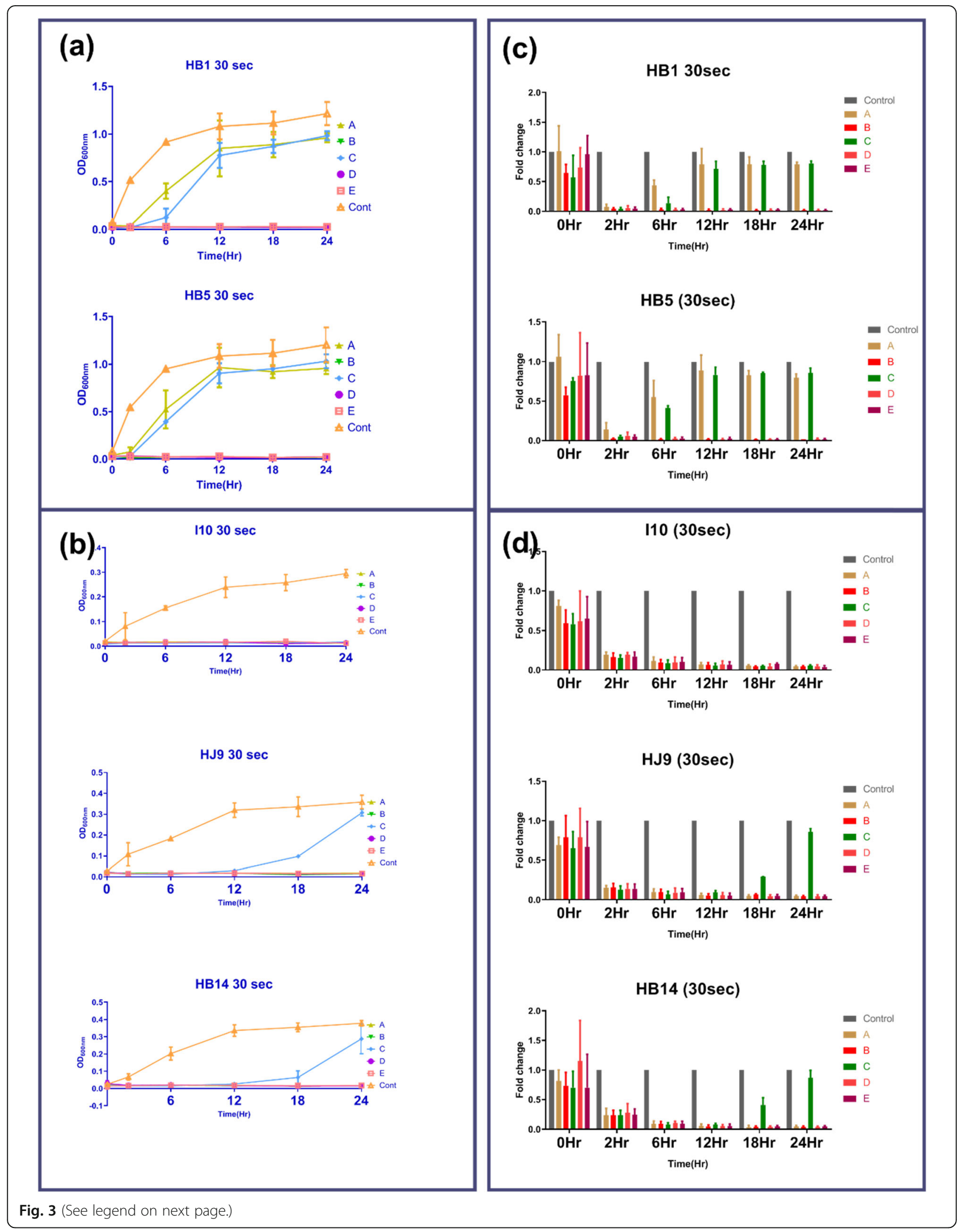


(See figure on previous page.)

Fig. 3 Growth pattern of H. pylori isolates after treatment with oral rinses for $30 \mathrm{~s}$. Treatment of oral rinses (A, B, C, D, and E) was given to $6 \times 10^{7}$ of $\mathrm{H}$. pylori for $30 \mathrm{~s}$, and growth was observed until $24 \mathrm{~h}$ compared to untreated control. Graphs reflect the growth of (a) fast (HB1 and HB5) and (b) slow-growing (HJ9, HB14, and I10) isolates. Relative growth of (c) fast (HB1 and HB5) (d) slow-growing (I10, HJ9, and HB14) was estimated compared to untreated control. The data are the mean \pm SD of two independent experiments with technical replicate $(n=4, \mathrm{mean} \pm \mathrm{SD})$

PTEN, and MMP7 were also included [27-30]. A mixed expression profile was observed on treatment with oral rinses $(\mathrm{B}, \mathrm{C}, \mathrm{D}$, and $\mathrm{E})$ for $5 \mathrm{~s}$ in the $\mathrm{I} 10$ strain. On treatment with solution $\mathrm{B}, \mathrm{H}$. pylori genes (16 s rRNA, CagA, and BabA) and GC markers (CCND1, PTEN, and MMP7) were down-regulated. However, expression was higher in CDX2 with $5 \mathrm{~s}$ treatment to $H$. pylori, followed by $12 \mathrm{~h}$ incubation with gastric epithelial cells. H. pylori genes, $16 \mathrm{~s}$ rRNA, and Cag A are down-regulated with the treatment of $\mathrm{C}$ and $\mathrm{E}$ (except HJ9) while Bab A was down-regulated with $C$ (Fig. 6c, e). Moreover, PTEN and MMP7 were down-regulated with oral rinse solutions B, $\mathrm{C}$, and $\mathrm{E}$ (Fig. $6 \mathrm{k}, \mathrm{m}$ ). Interestingly, $30 \mathrm{~s}$ treatment to $\mathrm{I} 10$ was able to abolish the expression of $16 \mathrm{~s}$ rRNA; CagA; and BabA with solution B; B, C, D, and E; and B, C, and $\mathrm{E}$, respectively (Fig. $6 \mathrm{~b}$ ). Our results also revealed that expression of CDX2; and MMP7 were higher with solutions $\mathrm{C}, \mathrm{D}, \mathrm{E} ; \mathrm{B}, \mathrm{C}$, and $\mathrm{D}$ respectively with the $30 \mathrm{~s}$ treatment at $12 \mathrm{~h}$ time point (Fig. 6j, n). Similarly, when we treated another slow-growing strain HJ9 for $5 \mathrm{~s}$ with oral rinses followed by incubation with AGS. Strikingly a mixed response in gene expression profiling. In the case of PTEN; and MMP7, the expression is moderately enhanced with solutions $\mathrm{C}, \mathrm{D}$, and $\mathrm{E} ; \mathrm{B}, \mathrm{C}$, and $\mathrm{D}$, respectively. Whereassolution $\mathrm{B}$ and $\mathrm{E}$ were able to diminish the expression of PTEN and MMP7, respectively (Fig. 6l, n). $30 \mathrm{~s}$ treatment of oral rinse $B$ to the same strain followed by incubation shows slight downregulation in the expression of $16 \mathrm{~s}$ rRNA, CagA, BabA, CCND1, CDX2, and PTEN, however, the expression of MMP7 was an exception (Fig. 6). Further, when we treated HB14, another slow-growing strain, for $5 \mathrm{~s}$ with oral rinses solution followed by incubation with AGS, CagA, BabA, CCND1, CDX2, and MMP7 was considerably down-regulated with solution B (Fig. 6). Additionally, CCND1, CDX2, and MMP7 were minimally expressed with the treatment of $\mathrm{B}, \mathrm{C}$, and $\mathrm{E}$, while PTEN is downregulated with E (Fig. 6). Moreover, treatment of HB14 for $30 \mathrm{~s}$ and incubation with AGS, also leads to the downregulation of CCND1, CDX2, and PTEN with C, $D$, and $E$, while expression of MMP7 was unregulated with C, D, and E (Fig. 6n). However, CagA was abolished with B, C, and D (Fig. 6).

Furthermore, results reflect different gene expression profiles with the treatment of 5 and $30 \mathrm{~s}$ in fast-growing strain HB1 (Fig. 6). Expression of CagA; and BabA were down-regulated with the treatment of $\mathrm{B}, \mathrm{D}$, and $\mathrm{E}$; and $\mathrm{B}, \mathrm{C}, \mathrm{D}$, and E, respectively (Fig. 6c, e). Whereas the expression of CCND1; CDX2; and MMP7 were enhanced with B, C, D and E; E; and B, respectively (Fig. $6 \mathrm{~g}, \mathrm{i}, \mathrm{m})$. Treatment for $30 \mathrm{~s}$ to $\mathrm{HB} 1$ shows a minimal expression of CagA with solution B, C, and D, while; MMP7 was up-regulated with all the oral rinses (Fig. 6d, n). Induction of apoptosis in the cancer cell is one of the widely used treatment regimes against cancer [31]. Hence we have assessed apoptotic pathways that may be induced after growth inhibition of $H$. pylori due to the treatment of oral rinses.

\section{Status of apoptotic gene expression}

Earlier studies have classified cells as live, apoptotic, and necrotic after $\mathrm{EB} / \mathrm{AO}$ staining [32]. We investigated these cells (live, apoptotic, and necrotic) on infection with H. pylori treated with oral rinses for $30 \mathrm{~s}$ (Fig. 7). Additionally, the evaluation of apoptotic pathways, such as intrinsic/extrinsic/independent, was performed after treatment of $H$. pylori isolates with these solutions for 5 and $30 \mathrm{~s}$ through qRT-PCR (Fig. 8). $5 \mathrm{~s}$ exposure of solution D in I10 strain was able to enhance the expression of APAF1, BID, and BAK (Fig. 8c, e, g). Interestingly, I10 treated with solution $\mathrm{C}$ and incubated with AGS cells were able to suppress all studied apoptotic genes (Fig. 8). Whereas, other solutions were not able to change the expression patterns of these genes considerably. Furthermore, $30 \mathrm{~s}$ treatment of $\mathrm{I} 10$ and incubation with AGS cells show a different pattern (Fig. 8). I10 treated with solution $\mathrm{B}$ was able to reduce the expression of all the selected genes except FADD (Fig. 8). However, treatment with solution $\mathrm{D}$ and $\mathrm{E}$ were slightly enhancing the expression of all pro-apoptotic genes (Fig. 8).

Furthermore, when we applied these solutions for $5 \mathrm{~s}$ on HJ9 and incubated with AGS cells, an upsurge in APAF1 expression, while BCL2 found down-regulated except in solution D (Fig. 8c, m). Surprisingly, $30 \mathrm{~s}$ treatment of HJ9 reflected a varied gene expression compared to $5 \mathrm{~s}$. Oral rinse $\mathrm{C}, \mathrm{D}$, and $\mathrm{E}$ with $30 \mathrm{~s}$ exposure were able to up-regulate all apoptotic genes except NOXA and PUMA (Fig. 8). However, the expression of anti-apoptotic BCL2 was reduced with oral rinse B (Fig. 8n).

Application of these oral rinses for $5 \mathrm{~s}$ on HB14 followed by incubation with AGS cells demonstrated that oral rinse D up-regulates all pro-apoptotic genes (Fig. 8). Interestingly, treatment with $B$ was able to enhance extrinsic apoptotic regulator FADD and reduce 


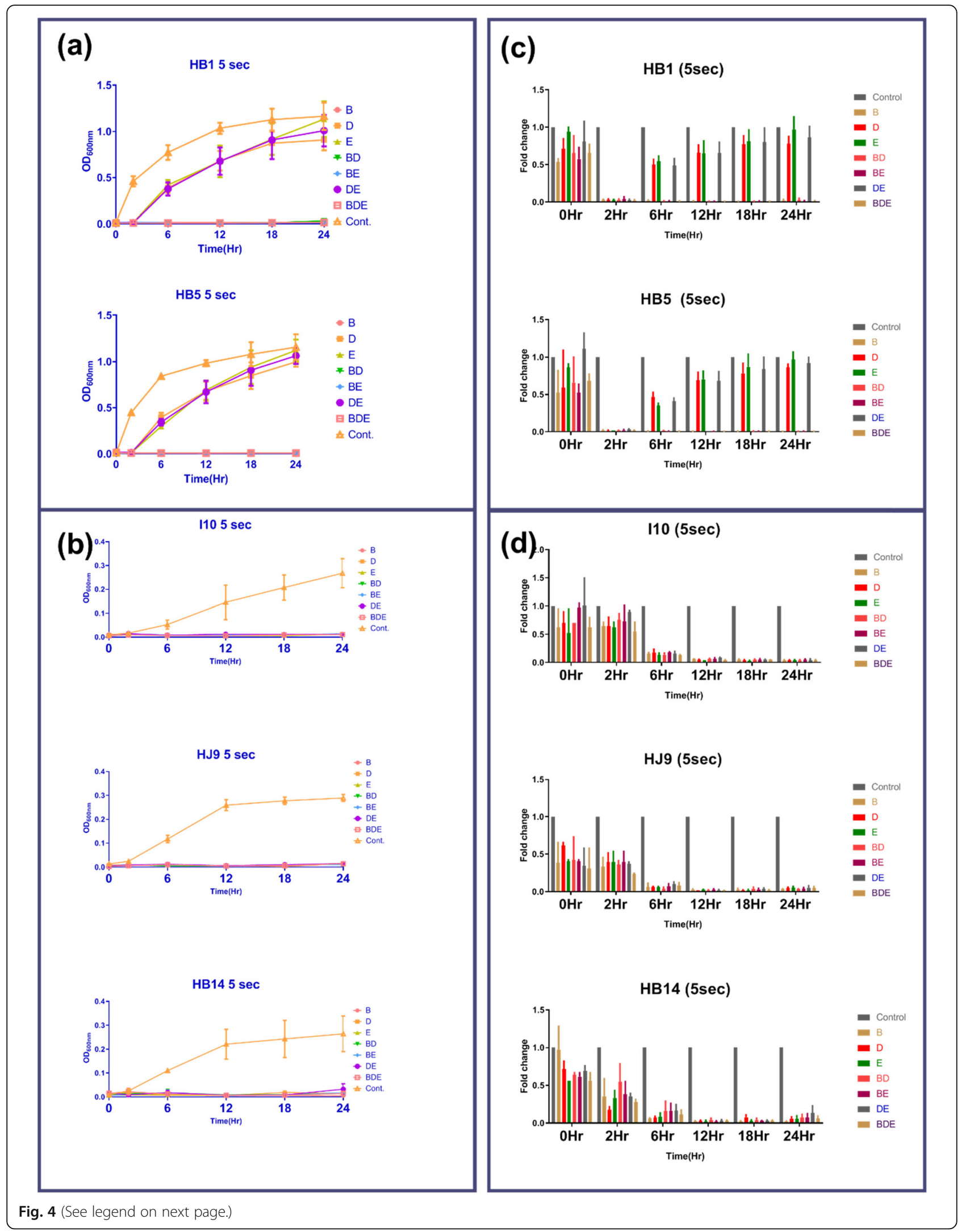


(See figure on previous page.)

Fig. 4 Treatment with selected oral rinses for a shorter duration. $6 \times 10^{7}$ of $\mathrm{H}$. pylori were treated with selected oral rinse alone and in combination $(B, D, E, B D, B E, D E$, and $B D E)$ for $5 \mathrm{~s}$. Growth was observed until $24 \mathrm{~h}$ in comparison to untreated control. Growth curve of (a) fast-growing isolates (HB1 and HB5) and (b) slow-growing isolates (HJ9, HB14, and 110). Relative growth of fast HB1 and HB5 (c) and in of slow-growing I10, $\mathrm{HJ9}$, and HB14 (d) compared to untreated control. The data are the mean \pm SD of two independent experiments with technical replicate $(n=4$, mean \pm SD)

the expression of all used intrinsic markers. It also diminished the expression of BCL2 (Fig. 8), fascinatingly, all apoptotic markers except PUMA were considerably down-regulated with the $30 \mathrm{~s}$ treatment of solution D (Fig. 8). Moreover, the expression of FADD, APAF1, and BAK, were also reduced with solution E (Fig. 8b, d, f).

Furthermore, in the case of fast-growing strain, HB1, solution $\mathrm{C}$ and $\mathrm{E}$ were slightly up-regulating the expression of FADD, APAF1, BID, and BAK (Fig. 8a, c, e). In addition to this, solution $B$ treated cells were able to upregulate FADD, APAF1, BID, and NOXA (Fig. 8a, c, g, k). Treatment of solution $C$ for $30 \mathrm{~s}$ to the same strain showed up-regulation of FADD, BID, and PUMA (Fig. $8 \mathrm{~b}, \mathrm{~h}, \mathrm{j}$ ). In contrary to this, slightly up-regulation was observed for BCL2 in all used solutions.

\section{Discussion}

Various studies suggest an association between $H$. pylori and GC [1]. Infection of $H$. pylori in less developed Asian countries like India, Pakistan, Thailand, and Bangladesh is more prevalent than in more developed Asian countries like Japan and China. Interestingly, the occurrence of GC is lower in these less-developed Asian countries compared to Japan and China [13]. A similar enigma has been reported from Africa as compared to the Western countries [33]. The prevalence of $H$. pylori infection and the occurrence of GC may not appear to be proportionate around the world [9]. This may be attributed to the variations in the $H$. pylori strain pathogenicity and other associated risk factors for GC. It is essential to understand the discrepancy in $H$. pylori pathogenicity due to geographical and host anatomical locations.

In the present study, we were able to demonstrate significantly different growth patterns of isolated $H$. pylori collected from gastric biopsy and juice samples. These findings motivated us to validate the growth pattern of various clinical $H$. pylori isolates through plate densitometry. The $H$. pylori isolation from two different niches of the same person may also lead to the differential growth pattern. For the first time, our study revealed that $H$. pylori isolated from the biopsy grow aggressively compared to those isolated from gastric juice of the same subject. For example, HJ1 and HB1; HJ10 and HB10; and HJ14 and HB14 were isolated from two different niches of the same subjects. There was a significant difference in the growth pattern of HJ1 and
HB1, which was not much remarkable in the case of $\mathrm{HJ} 10$ and HB10, as well as HJ14 and HB14. This finding demonstrates the importance of infection sites and their micro-environment for $H$. pylori dependent disease progression. Similar findings have been reported in pneumococcal infection [34]. Hence, these results show a specific pattern for the adaptation of $H$. pylori, which may act as a milestone in disease progression and subjected to further investigation.

Earlier, Marshall et al. showed that $H$. pylori eradication resulted in rapid gastric ulcer healing (92\% vs. $61 \%)$ and lower relapse rate $(21 \%$ vs. $84 \%)$ than noneradication [35]. Importantly, resistance to antibiotic treatment is one of the major causes for the development of primary $H$. pylori infection to chronic gastritis and GC [36]. Studies reported that H. pylori isolated from the Indian population are resistant to its specific antibiotics [37]. Additionally, some strains of $H$. pylori are also resistant to triple therapy, which further increases the complication in the eradication procedure [38].

The transmission mode of $H$. pylori is an oral-oral or oro-fecal route [39]. Therefore, the oral cavity may serve as a reservoir for H. pylori [16]. Earlier studies demonstrated that relapse of $H$. pylori infection is mainly due to the presence of its extra-gastric reservoir in the oral compartment [40]. Hence, eradication of $H$. pylori in the mouth may help in restricting its transmission and relapse from mouth to stomach [21]. In our study, the approach is to eliminate $H$. pylori in the oral microenvironment using mouth rinses. It will further help in treating the infection and will enhance the treatment outcome in gastric abnormalities.

Various antiplaque and antimicrobial agents are known for inhibiting the growth or killing the target bacteria present in the oral microenvironment. These solutions may consist of chlorhexidine [41], essential oil [42], cetylpyridinium chloride [43], povidone-iodine [44], etc. In our study, we investigated the effect of these oral rinses on $H$. pylori growth and its carcinogenic abilities.

Based on differential growth observation of these isolates, we selected two fast (HB1 and HB5) and two slowgrowing strains (HJ9 and HB14), along with one reference strain I10, for further study. Oral rinses B, D, and $\mathrm{E}$, were efficient in killing fast-growing strains with $30 \mathrm{~s}$ incubation. In contrary to this, oral rinse $\mathrm{A}$ and $\mathrm{C}$ act as bacteriostatic and inhibit the growth until $2 \mathrm{~h}$. 


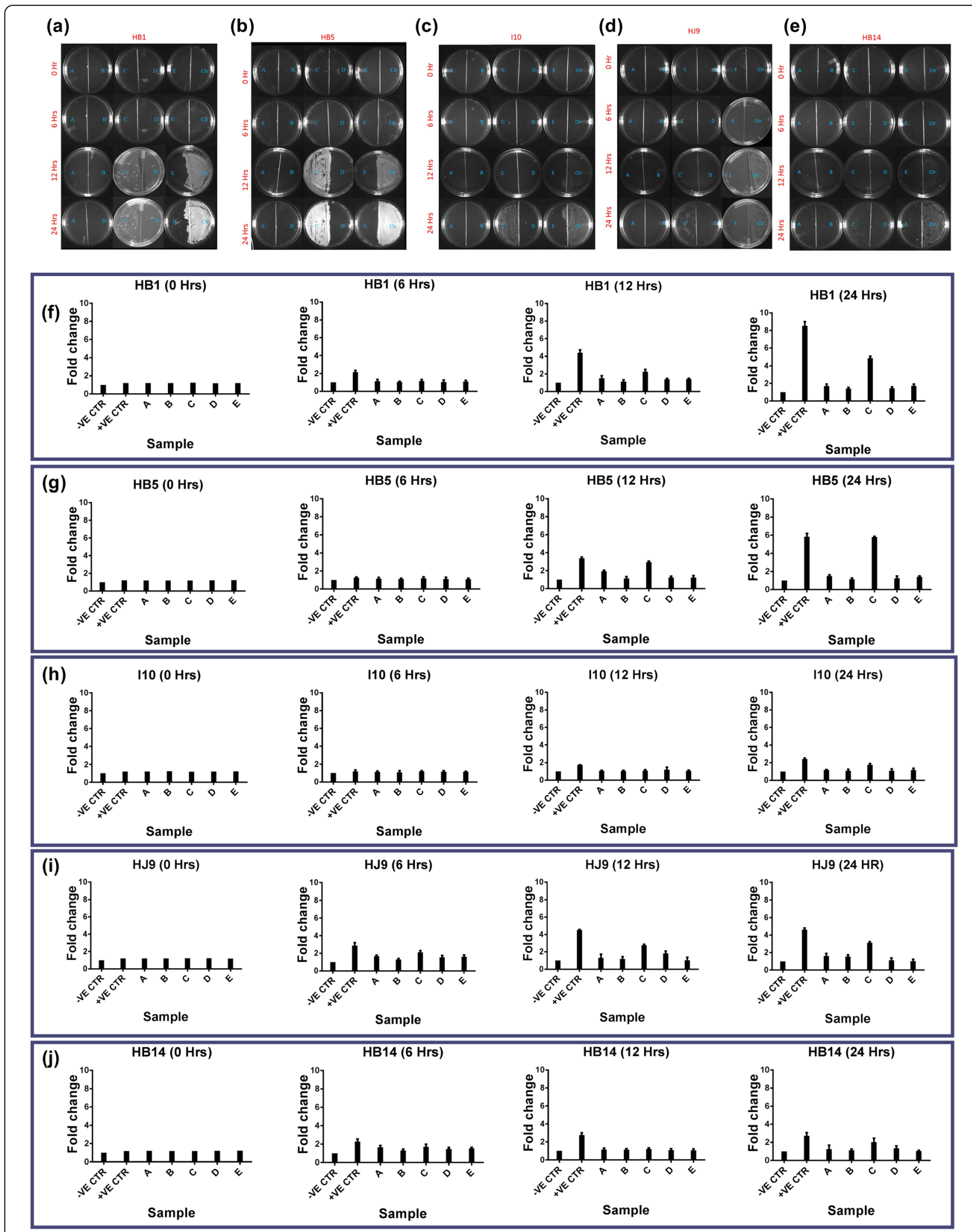

Fig. 5 (See legend on next page.) 
(See figure on previous page.)

Fig. 5 Plate densitometry of $\mathrm{H}$. pylori after treatment with oral rinses. Oral rinses treatment of $A, B, C$, D, and E was given to $1 \times 10^{7} \mathrm{H}$. pylori, followed by spreading on half of the BHI Agar plate. Representative images showing growth of (a) HB1, (b) HB5, (c) I10 (d) HJ9 and (e) HB14 till $24 \mathrm{~h}$ Relative growth was estimated for fast-growing isolates (f) HB1 and (g) HB5; and slow-growing isolates (h) I10, (i) HJ9, and (j) HB14. Blank plates were considered as negative control and untreated isolates as a positive control. The data are the mean \pm SD of two independent experiments with technical replicate $(n=4$, mean \pm SD)

Additionally, in the case of slow-growing strains (HJ9 and HB14), all used solutions except $\mathrm{C}$ are useful, while, solution $\mathrm{C}$ act as bacteriostatic up to $12 \mathrm{~h}$. Interestingly, all used oral rinses were found to be efficient in killing reference strain I10, which has been grown for a long time in laboratory conditions. In order to understand the pathogenic islands of various clinical isolates, there is a need for further investigation of differential oral rinse response in clinical isolate vs. reference strain even though their growth patterns are similar.

To further validate the above experiment, plate densitometry was performed. It was observed that the growth of fast-growing strains (HB1 and HB5) with the treatment of solution $\mathrm{C}$ was detected at $12 \mathrm{~h}$ in comparison to $6 \mathrm{~h}$ of untreated. However, in liquid culture growth was observed at $6 \mathrm{~h}$ compared to $2 \mathrm{~h}$ in untreated. The growth of isolated strains (HJ1, HB4, HJ9, HB10, HJ10, HB14, and HJ14) was similar to the reference strain I10, whereas, HB1 and HB5 show about 15 fold higher growth after $12 \mathrm{~h}$. These fast-growing strains reflect higher growth at 2 and $6 \mathrm{~h}$ by 4 and 9 folds, respectively.

Importantly, the growth of HB1 and HB5, which was observed with solution A treatment in liquid culture, was not visible in the plate densitometry. Moreover, the growth of wild type fast-growing strains could be detected within $2 \mathrm{~h}$ in liquid culture compared to $6 \mathrm{~h}$ in plate densitometry.

The use of oral rinse is a common practice, while prolonged and repetitive use of these oral rinses has adverse effects on the users [45, 46]. A study conducted by McGaw \& Belch shows negligible toxicity associated with the use of chlorhexidine mouth rinses through radiolabeling methods [47]. However, such studies were conducted in the 1980s; hence, further investigations with modern detection techniques are needed in long term follow-up. Research on povidone-iodine, reveals that it can cause acute renal failure, mainly when absorbed through mucosal surfaces $[48,49]$. Even diluted solutions of povidone-iodine (0.1 to $20 \%)$ are toxic to human fibroblasts, granulocytes, and monocytes [50]. Toxicity of another solution, cetyl pyridinium chloride, is noticed with vomiting, diarrhea, and abdominal pain. Ingestion of this solution in concentrated form may produce burns of the mouth, pharynx, and esophagus [51]. Additionally, hemorrhagic GI tract necrosis and peritonitis have also been reported [51]. Prolonged exposure of common constituents of oral rinses like essential oils, menthol, thymol can act as potential allergens in various ethnical races [52]. Moreover, some manufacturers produce alcohol-based mouthwashes, which can cause complications like irritation of oral mucosa and may be hazardous if ingested accidentally during pregnancy [53].

One of our focus in this study was to reduce the time of exposure to minimize the possibility of toxicity caused by these solutions. To achieve our goal, we performed the $5 \mathrm{~s}$ treatment and compared it with $30 \mathrm{~s}$ treatment of H. pylori isolates. We selected those oral rinses which were efficient in the $30 \mathrm{~s}$ treatment in combinations and alone. As expected, the growth of slow-growing strains (I10, HJ9, and HB14) was controlled through all used oral rinses at $5 \mathrm{~s}$ incubation. However, only solution $\mathrm{B}$ and its combination seem to be potent for all H. pylori strains. Strikingly, oral rinses D and E, which were potent on $30 \mathrm{~s}$ treatment, have not shown comparable results with fast-growing strains. The high efficacy of solution B may be attributed to its sizeable dicationic molecule (Chlorhexidine), which can adsorb onto negatively charged bacterial cell walls [54]. This increases the permeability of the inner membrane and leads to the leakage of low molecular weight components. At $0.2 \%$ concentration, this damage is permanent and hence acts as a bactericidal agent [54].

The Cag pathogenicity island (cag-PAI) is one of the major virulence determinants of $H$. pylori. Irrespective of the growth pattern variation in isolated $H$. pylori strains, a significant downregulation of the CagA gene was observed with solution $\mathrm{B}$. Also, prolonged exposure to solution C and D to I10, HB14, and HB1 diminish the expression of CagA. Here Cag A expression imitates the growth of $H$. pylori after solution B treatment.

$\mathrm{EB} / \mathrm{AO}$ staining has been used as a gold standard to differentiate between live, apoptotic (early/late), and necrotic cells. We observed that $H$. pylori treated with solution B and incubated with AGS shows more cells in the late apoptotic stage. While with solution C, D, and E treatment, cells are either in the early apoptotic stage or live. This reflects that solution $\mathrm{B}$ is most effective among all the studied oral rinses. To understand the growth arrest of $H$. pylori through used oral rinses, we have mapped several mechanisms of cell death, mainly apoptosis and necrosis. Interestingly, extrinsic apoptotic marker FADD is slightly enhanced in slow-growing 


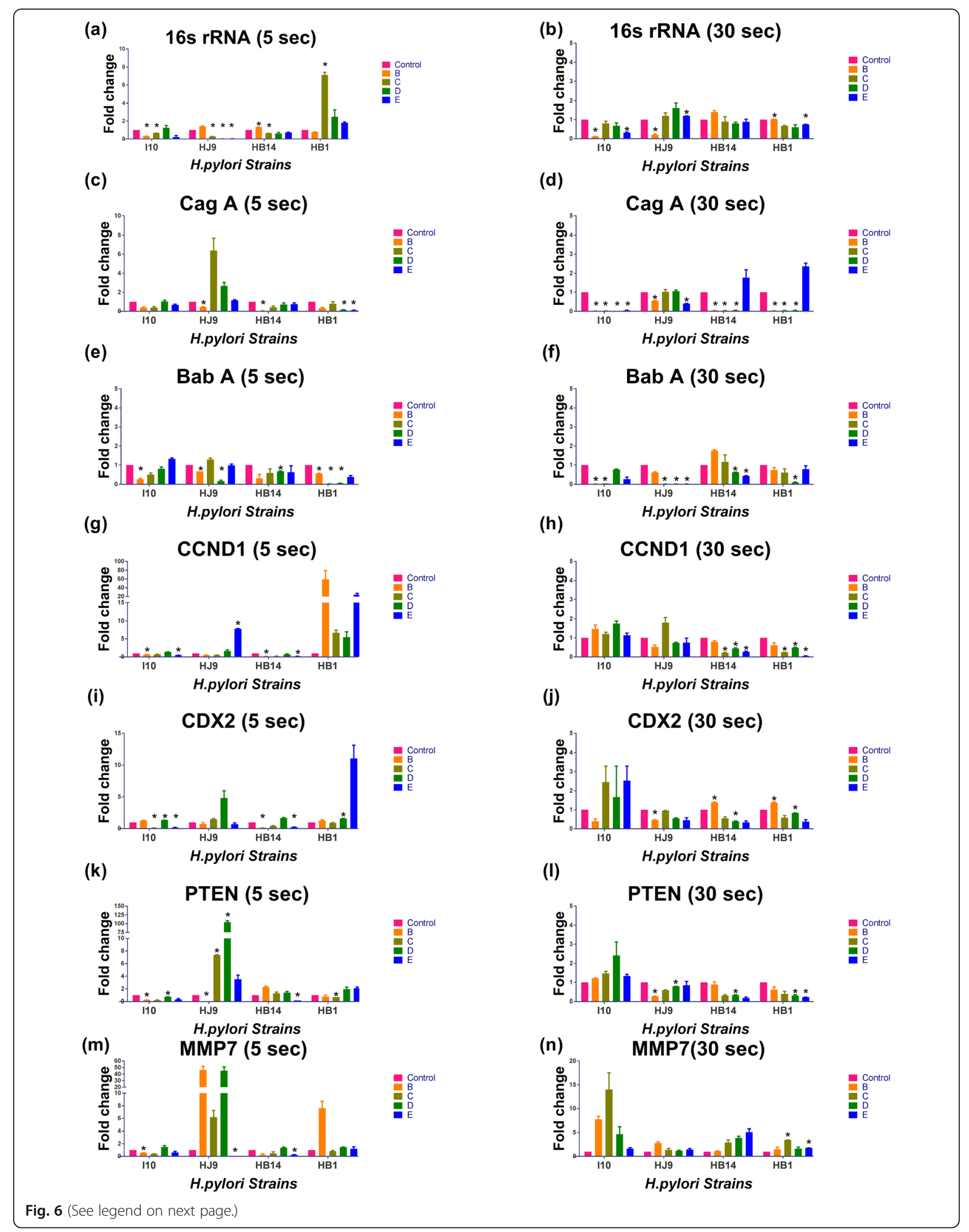


(See figure on previous page.)

Fig. 6 Investigation of H. pylori and gastric cancer genes: Treatment of solution was given to $6 \times 10^{7}$ of $\mathrm{H}$. pylori and incubated with $0.5 \times 10^{6}$ AGS cell for $12 \mathrm{Hrs}$. RNA was isolated, and transcript level was determined by qRTPCR. Experiments were performed in duplicates. Expression of $16 \mathrm{~s}$

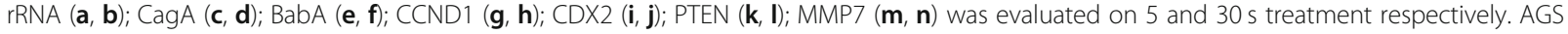
cells infected with wild type $H$. pylori treated as control in this study

strain HJ9 and HB14 with selective oral rinses. Although, studies suggest that FADD is expressed on the surface of cytotoxic T lymphocytes (CTLs) and natural killer (NK) cells as part of their armamentarium against infected or transformed cells [55].

Moreover, markers for the intrinsic pathway, APAF1 show higher expression during shorter exposure of solution $\mathrm{B}, \mathrm{C}, \mathrm{D}$, and $\mathrm{E}$ to $\mathrm{HJ}$, while the result is not similar for more prolonged exposure. Notably, BID shows selective up-regulation with solution $\mathrm{D}$ in slow-growing strains. Studies have demonstrated that both APAF1 and BID belongs to the BCL2 family and act with the mitochondria-related apoptotic pathway [56, 57]. However, expression pattern for BAK, PUMA, and NOXA was not decisive with used oral rinses $\mathrm{s}$ for all included H. pylori strains. PUMA and NOXA belong to the proapoptotic BH3 only family, which regulates BCL2 activity [58]. Interestingly, the anti-apoptotic gene, BCL2, was noticeably down-regulated in $5 \mathrm{~s}$ treatment while not in $30 \mathrm{~s}$ with the selected oral rinses.

\section{Conclusion}

H. pylori adaptation to different physiological habitat in the host may be responsible for the differences in its growth and pathogenicity. For avoiding the challenges of relapse and antibiotic resistance, we used oral rinses and found that these are effective against CagA expression in H. pylori. Some of the variability in outcome can be attributed to different bacterial strain specificity, host susceptibility, and the type of response elicited in the infected host. There is a need for a detailed study about the molecular pathways modulated by the oral rinses in bacteria and surrounded host cells. These studies will also open a broad scope to apply various bactericidal combinations for the treatment and eradication of $H$. pylori infection.

\section{Methods}

\section{Patient recruitment}

The endoscopic procedure was performed after getting informed written consent from the patients. The

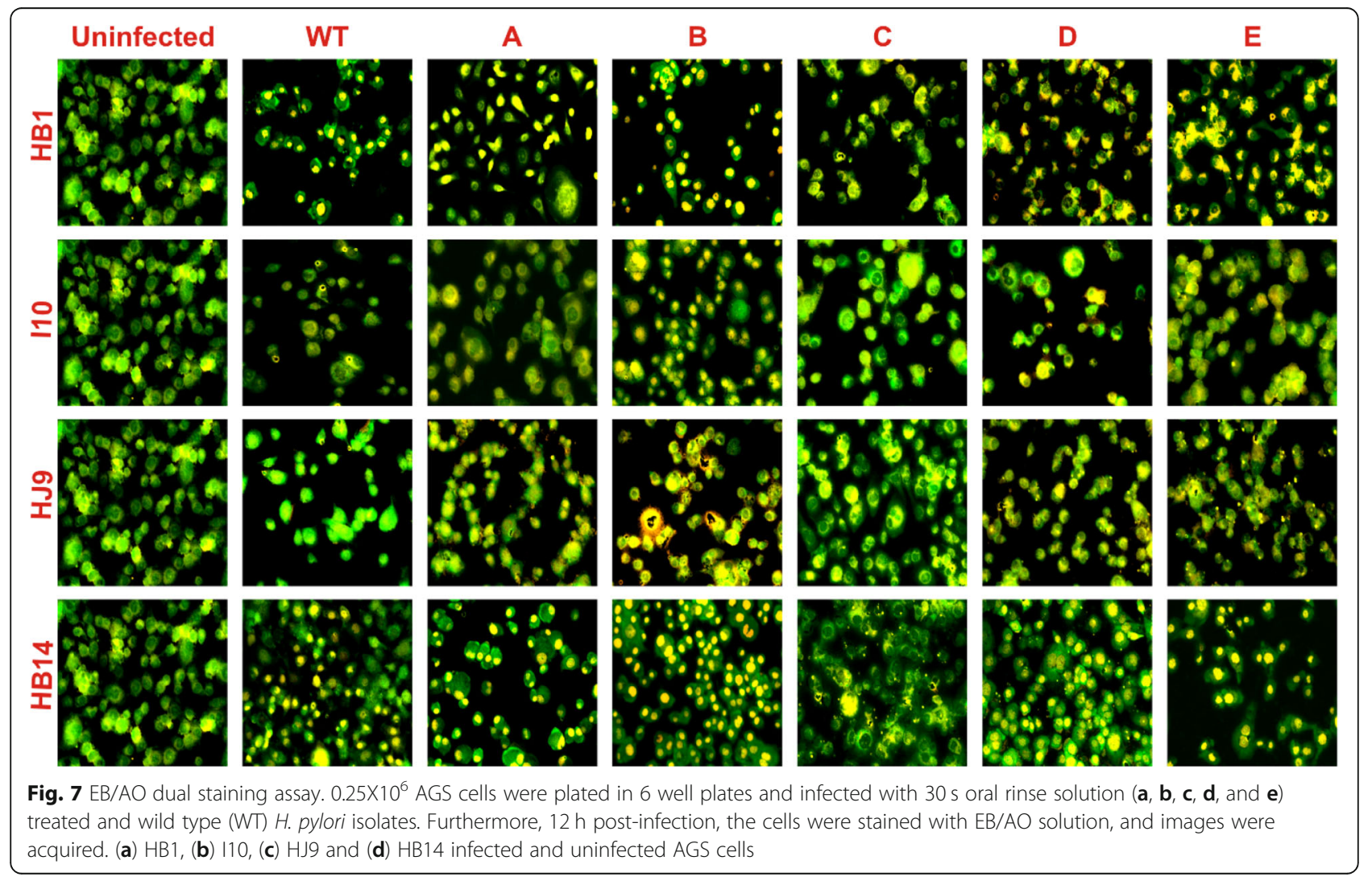




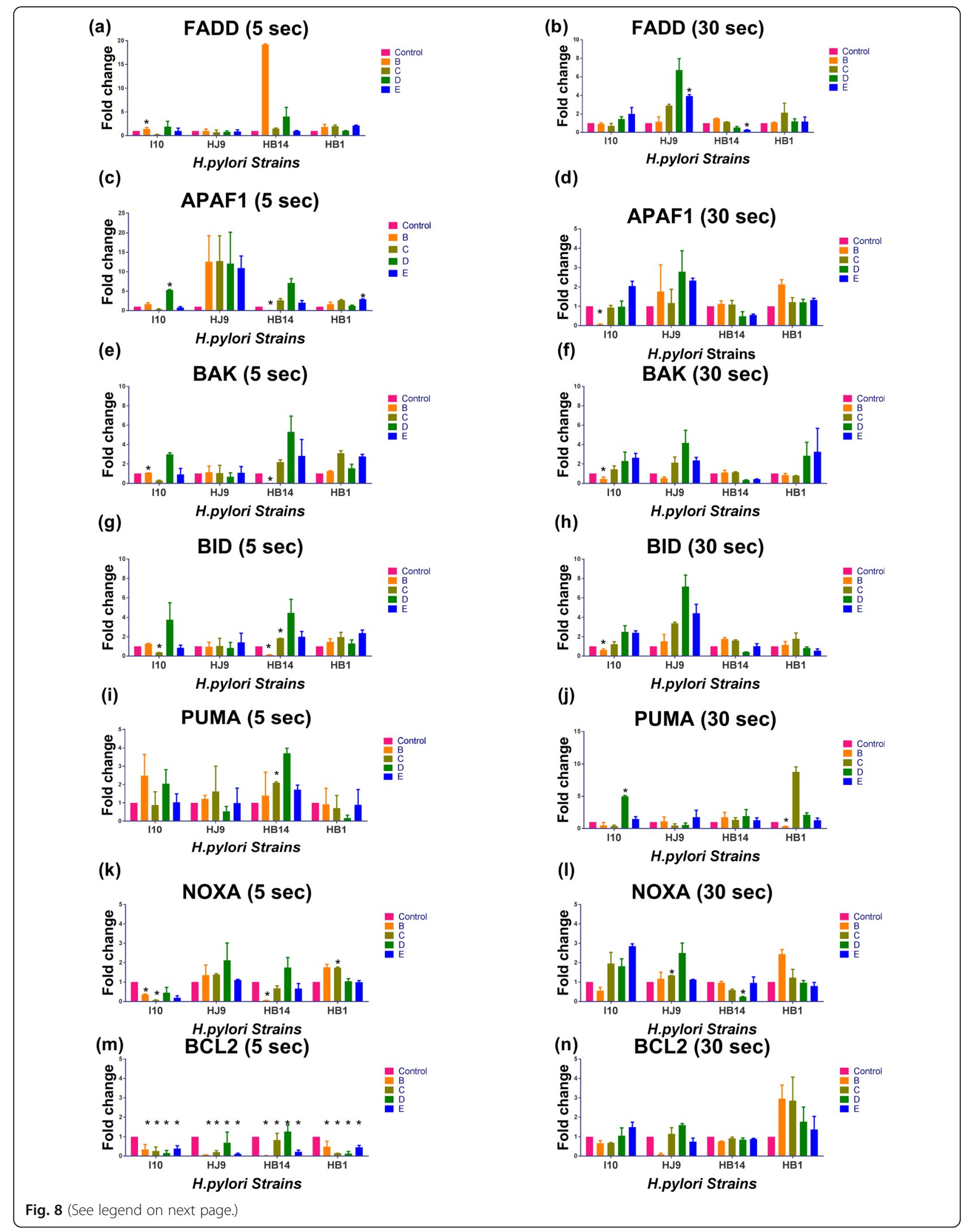


(See figure on previous page.)

Fig. 8 Status of apoptosis-related genes. Treatment of solution was given to $6 \times 10^{7}$ of $\mathrm{H}$. pylori and incubated with $0.5 \times 10^{6}$ AGS cell for 12 Hrs. RNA was isolated, and the transcript level was determined by qRTPCR. Experiments were performed in duplicates. Expression of (a, b) FADD; (c, d) APAF1; (e, f) BAK; ( $\mathbf{g}, \mathbf{h})$ BID; (i, j) PUMA; (k, I) NOXA; and $(\mathbf{m}, \mathbf{n})$ BCL2 was assessed after treatment for 5 and 30 s respectively. The data are the mean \pm SEM of two independent experiments with technical replicate $(n=4)$

protocol for the present study was approved by the ethical committee of the Indian Institute of Technology Indore, as well as Choithram Hospital Indore, and all procedures were performed by following the revised declaration of Helsinki 2000. Before collection of the sample written consent of the participants were obtained in a consent form. We collected only Rapid Urease Test $($ RUT) positive 14 biopsies (male $=9$ and female $=5$ ) and 11 gastric juice $($ male $=6$, female $=5)$ samples from gastritis patients (Table 1). Patients undergoing antibiotic treatment against $H$. pylori were excluded for sampling. For further processing, biopsy samples were immediately placed in a microcentrifuge tube containing Brucella broth (BD Difco Cat No. 8806541) with 20\% glucose (Hi-media, Cat No. TC130), while gastric juice was collected in sterile $15 \mathrm{ml}$ centrifuge tube. Samples were transported to IIT Indore in ice.

\section{Culturing of $H$. pylori from clinical samples}

The biopsy samples were homogenized by using a glass rod. One loopful of the homogenous sample was streaked on Columbia agar plate (Himedia ME144) containing the $H$. pylori selective antibiotics, $(5 \mathrm{mg} / \mathrm{L}$ cefsulodin, $10 \mathrm{mg} / \mathrm{L}$ vancomycin, $5 \mathrm{mg} / \mathrm{L}$ amphotericin $\mathrm{B}, 5$ $\mathrm{mg} / \mathrm{L}$ trimethoprim and $10 \%$ defibrinated blood, BD, Cat. No. 254005). The plates were incubated in a microaerophilic chamber (Whitley DG 250) containing specific growth conditions (i.e., $85 \% \mathrm{~N}_{2}, 10 \% \mathrm{CO}_{2}$ and $5 \% \mathrm{O}_{2}$ ) at $37^{\circ} \mathrm{C}$. The same procedure was followed for gastric juice samples, and the colonial growth was observed for the next 3-4 days. H. pylori isolated form biopsy and gastric juice samples were named as $\mathrm{HB}$ and $\mathrm{HJ}$, respectively, followed by a number representing the sequence of sampling. In the present study, we also used I10 as a reference $H$. pylori strain, which was kindly gifted by Dr. Ashish Kumar Mukhopadhyay from the National Institute of Cholera and Enteric Diseases (NICED) Kolkata.

\section{Culture of clinical isolates in liquid and solid growth medium}

A single colony was picked from the Columbia agar plate of each sample and inoculated in brain heart infusion media (BHI, Cat. No. 237500- BD Brain Heart Infusion broth), containing 10\% Fetal Bovine Serum (FBS Hi-media, Cat. No. RM-10432) with 3X H. pylori selective antibiotics in a snap cap tube (BD, Cat. No. 352001) [59]. Simultaneously, it was also streaked on a BHI agar plate containing the same concentration of FBS and antibiotics. Both broth and plate were incubated in a similar growth condition, as described above.

\section{Gram staining}

In order to identify isolated strains, Gram staining was performed. Preparation of smear was done after suspending a new culture in $100 \mu \mathrm{l}$ PBS followed by airdrying and heat-fixation over the flame. The smear was flooded with crystal violet for $60 \mathrm{~s}$, and the excess stain was washed off with distilled water. The smear was again flooded with Gram iodine for 60 s, followed by destaining with $95 \%$ ethanol. The slides were further rinsed with distilled water and blot dried, followed by counterstaining with safranin for $30 \mathrm{~s}$. The slides were again washed and observed under the microscope (100X - oil immersion lens) (Nikon Eclipse E100 upright microscope) (Fig. 1).

\section{Growth curve}

The isolated H. pylori strains were analyzed for the growth pattern until $24 \mathrm{~h}$. In brief, the isolates were cultured in a $14 \mathrm{ml}$ round bottom snap cap tube (BD) in biological duplicates by setting initial $\mathrm{OD}_{600} 0.05$, which correspond to approximately 80 million CFU per ml [59]. Further, they were incubated in the microaerophilic chamber, as mentioned above. $150 \mu$ grown culture was placed in duplicate in 96 well flat-bottom plates, and OD was recorded at $600 \mathrm{~nm}$ (Synergy H1 Hybrid MultiMode Reader, BioTek). The final OD value was normalized with media as a negative control.

\section{DNA isolation}

H. pylori culture was harvested in phosphate-buffered saline for DNA extraction at $\mathrm{OD}_{600 \mathrm{~nm}}$ of $0.2-0.6$. The pelleted cells were suspended in extraction solution (10 $\mathrm{mM}$ Tris $\mathrm{pH} 8.0,15 \mathrm{mM} \mathrm{NaCl}, 10 \mathrm{mM}$ EDTA, $0.5 \%$ SDS) and kept at $55^{\circ} \mathrm{C}$ for $1 \mathrm{~h}$. Proteinase $\mathrm{K}$ (Thermo fisher scientific) solution $(20 \mathrm{mg} / \mathrm{ml})$ was added $(1 \mathrm{mg} /$ $\mathrm{ml}$ ), and samples were incubated overnight at $37^{\circ} \mathrm{C}$. RNAse-A (Himedia) was added $(0.1 \mathrm{mg} / \mathrm{ml})$ to the solution and kept at $37^{\circ} \mathrm{C}$ for $1 \mathrm{~h}$. The DNA was then extracted with the phenol-chloroform-isoamyl-alcohol method, as reported previously [60].

\section{PCR detection}

H. pylori DNA samples were amplified by Platinum ${ }^{\mathrm{Tm}}$ Taq DNA Polymerase (Invitrogen ${ }^{\mathrm{Tw}}$, Cat. No.10966026). The reaction volume for PCR was $50 \mu \mathrm{L}(50 \mathrm{mM} \mathrm{KCl}$, 
$1.5 \mathrm{mM} \mathrm{MgCl} 2,200 \mathrm{mM}$ dNTPs, $10 \mathrm{mM}$ Tris- $\mathrm{HCl}(\mathrm{pH}=$ 8.3), 10 pmol primer, 2.5 units Taq polymerase and 100 ng of DNA template). $16 \mathrm{~s}$ rRNA specific forward primer 5' CTGGAGAGACTAAGCCCTCC 3' and reverse primer 5' ATTACTGACGCTGATTGCGC 3' respectively were used for amplification (product size $-110 \mathrm{bp}$ ). The amplification was carried out with initial denaturation at $95^{\circ} \mathrm{C}$ for $7 \mathrm{~min}$, followed by 40 cycles of denaturation, annealing, extension, and a final extension at $94{ }^{\circ} \mathrm{C}$ for 2 min, $55^{\circ} \mathrm{C}$ for $30 \mathrm{~s}, 72^{\circ} \mathrm{C}$ for $30 \mathrm{~s}$ and $72{ }^{\circ} \mathrm{C}$ for $10 \mathrm{~min}$ respectively. Analysis of the amplified products was done by gel electrophoresis using $2.5 \%$ agarose gel and stained with $0.5 \mu \mathrm{g} / \mathrm{ml}$ ethidium bromide. Product size was confirmed by using a 50-bp DNA ladder (Hi-Media, cat no. MBT130). The image of gel was acquired on a gel documentation system (ImageQuant LAS 4000, GE Healthcare Life Sciences).

\section{Oral rinses}

Five different commercially available mouthwash solutions were purchased from local pharmacy store and were assigned name A, B, C, D \& E. Mouthwash A contains cetylpyridinium chloride $0.075 \% \mathrm{w} / \mathrm{w}$, mouthwash B contains chlorhexidine $(0.2 \% \mathrm{w} / \mathrm{v})$, mouthwash $\mathrm{C}$ contains naturally derived clove oil $(0.1 \mathrm{mg} / \mathrm{gm})$ (cloves extracts), mouthwash D contains thymol (thyme) 0.064\%, methyl salicylate (wintergreen) $0.06 \%$ and eucalyptol (eucalyptus) $0.092 \%$, and mouthwash E contains $2 \% \mathrm{w} / \mathrm{v}$ povidone-iodine.

\section{Confirmation of the active component of oral rinses through LC-MS}

Mass and spectral analysis were done by Bruker Daltonik, Benchtop, High-Performance Electrospray Ionization Quadrupole time-of-flight LC-MS spectrometer designed for estimation of an exact mass of the components present in mouthwash solutions. The bactericidal function of cetyl-pyridinium chloride (CPC) or 1-hexadecyl pyridinium chloride or chlorhexidine gluconate $(\mathrm{CHG})$, clove oil, menthol/thymol, and povidone/iodine is well known and used in various antibacterial products like mouthwashes, throat sprays, nasal sprays.

\section{H. pylori growth inhibition by oral rinses}

Povidone-iodine $(2 \%)$ was diluted in water (1:1), while other mouthwashes were used in provided concentrations. A fixed number of $H$. pylori $\left(6 \times 10^{7}\right)$ were incubated with $1 \mathrm{ml}$ of all mouthwashes for $30 \mathrm{~s}, 10 \mathrm{~s}$, and 5 $\mathrm{s}$, followed by centrifugation at $3000 \mathrm{rpm}$ for $5 \mathrm{~min}$. The control group was left untreated. Pellets were suspended in $0.5 \mathrm{ml}$ of BHI media containing 10\% FBS and selective antibiotics followed by incubation in microaerophilic conditions, as mentioned above. $150 \mu \mathrm{l}$ of culture was taken in each well in duplicates in a flat bottom 96 well plate, and optical density was recorded at $600 \mathrm{~nm}$ (Synergy $\mathrm{H} 1$ microplate reader, Biotek) at $0,6,12,18$, and $24 \mathrm{~h}$ time points, and growth curve was plotted.

\section{Densitometry of $\mathrm{H}$. pylori growth on $\mathrm{BHI}$ agar plate}

A plate densitometry study on a BHI agar plate was performed to validate the growth pattern in the liquid medium. In order to check the growth of H. pylori (HB1, HB5, HJ9, HB14, and I10) on BHI agar plate, $1 \times 10^{7}$ bacteria were taken $\left(\mathrm{OD}_{600} 0.3\right.$ represents 500 million CFU per ml) [59] and suspended in $100 \mu \mathrm{L}$ of BHI broth and then spread by using glass spreader. Further, images of plates were obtained at $0,6,12$, and $24 \mathrm{~h}$, and data were analyzed by measuring the mean grey value using Image J software (NIH) (Fig. 2c). In addition to this, the growth of bacteria on a BHI agar plate after $30 \mathrm{~s}$ solution treatment was also determined. $0.5 \times 10^{7}$ bacteria were taken and subjected to centrifugation at $3000 \mathrm{rpm}$ for $5 \mathrm{~min}$. The supernatant was discarded, and the pellet was treated with $333 \mu \mathrm{L}$ of the selected oral rinses $(\mathrm{A}, \mathrm{B}, \mathrm{C}$, $\mathrm{D}$, and $\mathrm{E}$ ) for $30 \mathrm{~s}$. The treatment was stopped by centrifugation at $3000 \mathrm{rpm}$ for $5 \mathrm{~min}$, and the supernatant was discarded. The pellets were suspended in $50 \mu \mathrm{L}$ of BHI broth and spread in half of the plate and incubated in a microaerophilic condition followed by taking an image at various time intervals (Fig. 5). We have shown representative images of $H$. pylori growth on BHI plates. Further, for better understanding, we calculated the fold change in growth, and the obtained data were plotted into graph Fig. 2(c, d) and Fig. 5.

\section{RNA isolation and gene expression study through qRT- PCR}

Fixed number $\left(6 \times 10^{7} \mathrm{CFU}\right.$ per $\left.\mathrm{ml}\right)$ of $H$. pylori isolates (I10, HJ9, HB14, HB1) were treated with $1 \mathrm{ml}$ of oral rinse for $30 \mathrm{~s}$ and $5 \mathrm{~s}$. Here, oral rinse A was excluded from cell culture study because of alcoholic constituents. Further, $H$. pylori isolates were incubated with AGS cells under specific conditions $\left(5 \% \mathrm{CO}_{2}, 37^{\circ} \mathrm{C}\right)$ for $12 \mathrm{~h}$. At $12 \mathrm{~h}$ time point, the pellet was collected by centrifugation $(1600 \mathrm{rpm}$ for $5 \mathrm{~min}$ ) and washed twice with PBS. Total RNA was isolated by using Ribozol reagent $\left(V_{W} R^{\mathrm{mix}}\right.$ Cat No. N580) as per the manufacturer's instruction. cDNA was synthesized using the PrimeScript 1st strand cDNA Synthesis Kit (Takara, Cat No. RR820Q) according to the manufacturer's instruction. Quantitative real-time PCR (qRT-PCR) analysis was performed using the AriaMx Real-Time PCR System (Agilent technologies 5301 Stevens Creek Blvd Santa Clara, CA 95051 USA), for assessment of gastric cancer marker genes (CCND1, CDX2, PTEN, and MMP7), apoptotic genes (FADD, APAF1, BID, BAK, NOXA, PUMA and BCL2) and pathogen-associated genes (CagA, BabA, and 16 s-rRNA), (Supp. Table 1). 


\section{Ethidium bromide and acridine orange (EB/AO) assay} $\mathrm{EB} / \mathrm{AO}$ dual staining was performed for the assessment of the apoptotic, necrotic, and live-cells after infection with oral rinses treated $H$. pylori. The experiment was performed in duplicates, and the image was acquired by confocal microscopy (Olympus IX83) at 10X with 3X zoom in triplicates. The working concentration of acridine orange and ethidium bromide was $100 \mu \mathrm{g} / \mathrm{ml}$ each [61].

\section{Supplementary information}

Supplementary information accompanies this paper at https://doi.org/10. 1186/s12866-020-01728-4.

Additional file 1: Figure S1. Growth pattern of $H$. pylori isolates after treatment of solutions for $10 \mathrm{sec}$. Figure S2. Confirmation of chemical plaque control agents through LCMS Table S1. Genes specific primers included in this study.

\section{Abbreviations}

AlpA: Adhesins associated protein A; BabA: Blood group antigen binding adhesin A; BAK: BCl-2 homologous antagonist/killer; BCL2: Apoptosis regulator $\mathrm{BCl}-2$; $\mathrm{BID}$ : $\mathrm{BH} 3$-interacting domain death agonist; CagA: Cytotoxinassociated gene A; CCND1: Cyclin D1; CDX2: Caudal type homeobox 2; CFU: Colony Forming Unit; FADD: FAS-associated death domain; HB: Human Gastric Biopsy; HJ: Human Gastric Juice; Hop: Hope family outer protein; MMP7: Matrix Metallopeptidase 7; NOXA: Phorbol-12-myristate-13-acetateinduced protein 1; OD: Optical Density; OiP: Outer membrane associated protein; PTEN: Phosphatidylinositol 3,4,5-trisphosphate 3-phosphatase and dual-specificity protein phosphatase; PUMA: Bcl-2-binding component 3; SabA: Sialic acid-binding adhesion

\section{Acknowledgments}

We appreciate Dr. Ashish Kumar Mukhopadhyay (National Institute of Cholera and Enteric Diseases, Kolkata) for providing the Helicobacter pylori strain 110. We are thankful to Ms. Gayatree Mishra and Mr. Prajwal M for their voluntary help in some experiments. We also appreciate the Sophisticated Instrumentation Centre, IIT Indore for Confocal microscopy, and LC-MS facility.

\section{Authors' contributions}

$\mathrm{HCJ}$ coordinated the project and designed experiments. CS, DC, and AKJ collected samples from patients. DK, BB, TPV carried out experiments. BB and TPV analyzed data. DK, BB, and TPV wrote the manuscript. All authors read and approved the manuscript.

\section{Funding}

This project was supported by the Council of Scientific and Industrial Research grant no 37(1693)/17/EMR-II and Department of Science and Technology as Ramanujan fellowship grant no. SB/S2/RJN-132/20/5. DSTEMR: EMR/2017/001637. The funders have no role in designing the study, collection, analysis and interpretation of data and writing the manuscript.

\section{Availability of data and materials}

All-important data are presented in the manuscript or supplementary figures. Some other supporting information that may not be crucial or affecting result interpretation is not included. Moreover, these data can be available from the corresponding author on a reasonable request.

\section{Ethics approval and consent to participate}

The protocol for the present study was approved by the ethical committee of the Indian Institute of Technology Indore, as well as Choithram Hospital Indore (approval number FD090), and all procedures were performed by following the revised declaration of Helsinki. Before collection of the sample written consent of the participants were obtained in a consent form.
Consent for publication

Not applicable.

\section{Competing interests}

The authors declare that they have no competing interests.

\section{Author details}

${ }^{1}$ Discipline of Biosciences and Biomedical Engineering, Indian Institute of Technology Indore, 453552 Indore, Madhya Pradesh, India. ${ }^{2}$ Choithram Hospital and Research Centre, 452014 Indore, Madhya Pradesh, India.

Received: 26 October 2019 Accepted: 14 February 2020

Published online: 04 March 2020

\section{References}

1. Yamaoka Y. Mechanisms of disease: Helicobacter pylori virulence factors. Nat Rev Gastroenterol Hepatol. 2010;7:629-41.

2. Ishihara K, Miura T, Kimizuka R, Ebihara Y, Mizuno Y, Okuda K. Oral bacteria inhibit helicobacter pylori growth. FEMS Microbiol Lett. 1997;152:355-61.

3. Kusters JG, van Vliet AHM, Kuipers EJ. Pathogenesis of helicobacter pylori infection. Clin Microbiol Rev. 2006;19:449-90.

4. Bravo D, Hoare A, Soto C, Valenzuela MA, Quest AF. Helicobacter pylori in human health and disease: mechanisms for local gastric and systemic effects. World J Gastroenterol. 2018;24:3071-89.

5. Mishra S. Is helicobacter pylori good or bad? Eur J Clin Microbiol Infect Dis. 2013:32:301-4

6. Porras-Hurtado L, Ruiz Y, Santos C, Phillips C, Carracedo Á, Lareu M. An overview of STRUCTURE: applications, parameter settings, and supporting software. Front Genet. 2013:4:98.

7. Pritchard JK, Stephens M, Rosenberg NA, Donnelly P. Association mapping in structured populations. Am J Hum Genet. 2000;67:170-81.

8. Moodley Y, Linz B, Bond RP, Nieuwoudt M, Soodyall H, Schlebusch CM, et al. Age of the association between helicobacter pylori and man. PLoS Pathog. 2012;8:e1002693.

9. Brenner $\mathrm{H}$, Rothenbacher $\mathrm{D}$, Arndt V. Epidemiology of stomach cancer. In: Cancer Epidemiology: Springer; 2009. p. 467-77.

10. Pourhoseingholi MA, Vahedi M, Baghestani AR. Burden of gastrointestinal cancer in Asia; an overview. Gastroenterol Hepatol Bed Bench. 2015;8:19-27.

11. Servarayan Murugesan C, Manickavasagam K, Chandramohan A, Jebaraj A, Jameel ARA, Jain MS, et al. Gastric cancer in India: epidemiology and standard of treatment. Updat Surg. 2018;70:233-9.

12. Sankaranarayanan R, Ramadas K, Qiao Y. Managing the changing burden of cancer in Asia. BMC Med. 2014;12:3.

13. Singh $\mathrm{K}$, Ghoshal UC. Causal role of helicobacter pylori infection in gastric cancer: an Asian enigma. World J Gastroenterol: WJG. 2006;12:1346.

14. Graham DY, Lu H, Yamaoka Y. African, Asian or Indian enigma, the east Asian helicobacter pylori: facts or medical myths. J Dig Dis. 2009;10:77-84.

15. Ghoshal UC, Tiwari S, Pandey R, Dhingra S, Ghoshal U, Singh H, et al. Frequency of helicobacter pylori and CagA antibody in patients with gastric neoplasms and controls: the Indian enigma: 122. Am J Gastroenterol. 2005; 100:S64.

16. Gebara ECE, Faria CM, Pannuti C, Chehter L, Mayer MPA, Lima L. Persistence of helicobacter pylori in the oral cavity after systemic eradication therapy. J Clin Periodontol. 2006:33:329-33.

17. Yee JK. Helicobacter pylori colonization of the oral cavity: a milestone discovery. World J Gastroenterol. 2016;22:641.

18. Anand PS, Kamath KP, Anil S. Role of dental plaque, saliva and periodontal disease in helicobacter pylori infection. World J Gastroenterol: WJG. 2014;20: 5639-53.

19. Chugh TD. Emerging and re-emerging bacterial diseases in India. J Biosci. 2008;33:549-55.

20. Zarić S, Bojić B, Lj J, Dapčević B, Popović B, Čakić S, et al. Periodontal therapy improves gastric helicobacter pylori eradication. J Dent Res. 2009; 88:946-50.

21. Anand PS, Nandakumar K, Shenoy KT. Are dental plaque, poor oral hygiene, and periodontal disease associated with helicobacter pylori infection? J Periodontol. 2006;77:692-8.

22. Marsh PD. Controlling the oral biofilm with antimicrobials. J Dent. 2010;38: S11-5.

23. Baehni PC, Takeuchi Y. Anti-plaque agents in the prevention of biofilmassociated oral diseases. Oral Dis. 2003;9:23-9. 
24. Backert S, Clyne M, Tegtmeyer N. Molecular mechanisms of gastric epithelial cell adhesion and injection of CagA by helicobacter pylori. Cell Commun Signal. 2011;9:28

25. Amieva MR. El-Omar EM. Host-bacterial interactions in helicobacter pylori infection. Gastroenterology. 2008;134:306-23.

26. Backert S, Tegtmeyer N, Fischer W. Composition, structure and function of the helicobacter pylori cag pathogenicity island encoded type IV secretion system. Future Microbiol. 2015;10:955-65.

27. Shirin H, Moss SF. Helicobacter pylori induced apoptosis. Gut. 1998:43:592-4.

28. Kauser F, Hussain MA, Ahmed I, Ahmad N, Habeeb A, Khan AA, et al. Comparing genomes of helicobacter pylori strains from the high-altitude desert of Ladakh, India. J Clin Microbiol. 2005;43:1538-45.

29. Canales J, Valenzuela M, Bravo J, Cerda-Opazo P, Jorquera C, Toledo H, et al. Helicobacter pylori induced phosphatidylinositol-3-OH kinase/mTOR activation increases hypoxia inducible factor-1a to promote loss of cyclin D1 and G0/G1 cell cycle arrest in human gastric cells. Front Cell Infect Microbiol. 2017:7:92

30. Bai Z-G, Ye Y-J, Shen D-H, Lu Y-Y, Zhang Z-T, Wang S. PTEN expression and suppression of proliferation are associated with $C d \times 2$ overexpression in gastric cancer cells. Int J Oncol. 2013;42:1682-91.

31. Guo J, Li S, Guo G. Long noncoding RNA AFAP1-AS1 promotes cell proliferation and apoptosis of gastric cancer cells via PTEN/p-AKT pathway. Dig Dis Sci. 2017:62:2004-10

32. Ogden SR, Noto JM, Allen SS, Patel DA, Romero-Gallo J, Washington MK, et al. Matrix Metalloproteinase-7 and premalignant host responses in helicobacter pylori-infected mice. Cancer Res. 2010;70:30-5.

33. Sanpui P, Chattopadhyay A, Ghosh SS. Induction of apoptosis in Cancer cells at low silver nanoparticle concentrations using chitosan Nanocarrier. ACS Appl Mater Interfaces. 2011;3:218-28.

34. Ribble D, Goldstein NB, Norris DA, Shellman YG. A simple technique for quantifying apoptosis in 96-well plates. BMC Biotechnol. 2005;5:12.

35. Hooi JKY, Lai WY, Ng WK, Suen MMY, Underwood FE, Tanyingoh D, et al Global prevalence of helicobacter pylori infection: systematic review and meta-analysis. Gastroenterology. 2017;153:420-9.

36. Shenoy AT, Orihuela CJ. Anatomical site-specific contributions of pneumococcal virulence determinants. Pneumonia. 2016;8:7.

37. Ramakrishna BS. Helicobacter pylori infection in India: the case against eradication. Indian J Gastroenterol. 2006;25:25.

38. Ansari S, Yamaoka Y. Current understanding and management of Helicobacter pylori infection: an updated appraisal. F1000Research. 2018;7. https://doi.org/10.12688/f1000research.14149.1.

39. Datta S, Chattopadhyay S, Patra R, De R, Ramamurthy T, Hembram J, et al. Most helicobacter pylori strains of Kolkata in India are resistant to metronidazole but susceptible to other drugs commonly used for eradication and ulcer therapy. Aliment Pharmacol Ther. 2005;22:51-7.

40. Thyagarajan S, Ray P, Das BK, Ayyagari A, Khan AA, Dharmalingam S, et al. Geographical difference in antimicrobial resistance pattern of helicobacter pylori clinical isolates from Indian patients: multicentric study. J Gastroenterol Hepatol. 2003;18:1373-8.

41. Salles N, Mégraud F. Current management of helicobacter pylori infections in the elderly. Expert Rev Anti-Infect Ther. 2007;5:845-56.

42. Castro-Muñoz L, González-Díaz CA, Muñoz-Escobar A, Tovar-Ayona BJ, Aguilar-Anguiano LM, Vargas-Olmos R, et al. Prevalence of helicobacte pylori from the oral cavity of Mexican asymptomatic children under 5 years of age through PCR. Arch Oral Biol. 2017;73:55-9.

43. Mathur S, Mathur T, Srivastava R, Khatri R. Chlorhexidine: the gold standard in chemical plaque control. Natl J Physiol Pharm Pharmacol. 2011;1:45.

44. Marchetti E, Mummolo S, Di Mattia J, Casalena F, Di Martino S, Mattei A, et al. Efficacy of essential oil mouthwash with and without alcohol: a 3-day plaque accumulation model. Trials. 2011;12:262.

45. Hu D, Li X, Sreenivasan PK, DeVizio W. A randomized, double-blind clinical study to assess the antimicrobial effects of a cetylpyridinium chloride mouth rinse on dental plaque bacteria. Clin Ther. 2009:31:2540-8.

46. Roopashri G, Jayanthi K, Guruprasad R. Efficacy of benzydamine hydrochloride, chlorhexidine, and povidone iodine in the treatment of oral mucositis among patients undergoing radiotherapy in head and neck malignancies: a drug trail. Contemp Clin Dent. 2011;2:8-12.

47. Rath SK, Singh M. Comparative clinical and microbiological efficacy of mouthwashes containing 0.2 and $0.12 \%$ chlorhexidine. Dent Res J. 2013; $10: 364$
48. Patel R, Gallagher J, Chapple I. Question from practice: how to select the right mouthwash. Acute Pain. 2019;14:44.

49. McGaw WT, Belch A. Oral complications of acute leukemia: prophylactic impact of a chlorhexidine mouth rinse regimen. Oral Surg Oral Med Oral Pathol. 1985;60:275-80

50. Beji S, Kaaroud H, Ben FM, Abderrahim E, Zghidi S, Ben FH, et al. Acute renal failure following mucosal administration of povidone iodine. Presse Medicale Paris Fr 1983. 2006;35(1 Pt 1):61-3.

51. Gautam SS, Gautam RS. A case of ARF after chromopertubation with povidone iodine. Int J Reprod Contracept Obstet Gynecol. 2018;7:2982-4.

52. Balin AK, Pratt L. Dilute povidone-iodine solutions inhibit human skin fibroblast growth. Dermatol Surg Off Publ Am Soc Dermatol Surg Al. 2002; 28:210-4.

53. Pohanish RP. Sittig's handbook of toxic and hazardous chemicals and carcinogens. William Andrew; 2011.

54. Antignac E, Nohynek GJ, Re T, Clouzeau J, Toutain H. Safety of botanical ingredients in personal care products/cosmetics. Food Chem Toxicol. 2011; 49:324-41.

55. Reisfield GM, Goldberger BA, Pesce AJ, Crews BO, Wilson GR, Teitelbaum SA, et al. Ethyl glucuronide, ethyl sulfate, and ethanol in urine after intensive exposure to high ethanol content mouthwash. J Anal Toxicol. 2011;35:264-8

56. Jones CG. Chlorhexidine: is it still the gold standard? Periodontol. 1997:15: 55-62.

57. Wilson NS, Dixit V, Ashkenazi A. Death receptor signal transducers: nodes of coordination in immune signaling networks. Nat Immunol. 2009;10:348-55.

58. Patwardhan GA, Beverly $\sqcup$, Siskind $\sqcup$. Sphingolipids and mitochondrial apoptosis. J Bioenerg Biomembr. 2016;48:153-68.

59. Gryko M, Pryczynicz A, Zareba K, Kędra B, Kemona A, Guzińska-Ustymowicz $\mathrm{K}$. The expression of $\mathrm{BCl}-2$ and BID in gastric cancer cells. J Immunol Res. 2014;2014:1.

60. Youle RJ, Strasser A. The BCL-2 protein family: opposing activities that mediate cell death. Nat Rev Mol Cell Biol. 2008;9:47-59.

61. Blanchard TG, Nedrud JG. Laboratory maintenance of helicobacter species. Curr Protoc Microbiol. 2012;24:8B-1

62. Chachaty E, Saulnier P. Bacterial DNA extraction for polymerase chain reaction and pulsed-field gel electrophoresis. In: Nucleic acid protocols handbook, the. New Jersey: Humana Press; 2000. p. 33-6. https://doi.org/10. 1385/1-59259-038-1:33

63. Jha HC, Lu J, Saha A, Cai Q, Banerjee S, Prasad MAJ, et al. EBNA3C-mediated regulation of Aurora kinase $B$ contributes to Epstein-Barr virus-induced $B$ cell proliferation through modulation of the activities of the retinoblastoma protein and apoptotic Caspases. J Virol. 2013;87:12121-38.

\section{Publisher's Note}

Springer Nature remains neutral with regard to jurisdictional claims in published maps and institutional affiliations.
Ready to submit your research? Choose BMC and benefit from:

- fast, convenient online submission

- thorough peer review by experienced researchers in your field

- rapid publication on acceptance

- support for research data, including large and complex data types

- gold Open Access which fosters wider collaboration and increased citations

- maximum visibility for your research: over $100 \mathrm{M}$ website views per year

At BMC, research is always in progress.

Learn more biomedcentral.com/submissions 